\title{
Water Management and Planting Methods Influence Growth, Spikelet Sterility and Nutrient Acquisition in Aerobic Rice
}

\author{
Arjun Singh, Anchal Dass*, Shiva Dhar, C.V. Singh, S. Sudhishri, \\ Teekam Singh, G.A. Rajanna and Pooja Pande \\ ICAR-Central Rainfed Upland Rice Research Station (CRURRS), Hazaribagh, \\ Jharkhand-825302, India \\ *Corresponding author
}

\begin{tabular}{|l}
\hline Ke y w o r d s \\
$\begin{array}{l}\text { Adjuvant, Aerobic } \\
\text { rice, Irrigation, } \\
\text { Nutrient harvest } \\
\text { index, Partial factor } \\
\text { productivity, Spot- } \\
\text { planting, Sterility }\end{array}$ \\
\hline Article Info \\
\hline $\begin{array}{l}\text { Accepted: } \\
\text { 07 January } 2019 \\
\text { Available Online: } \\
\text { 10 February } 2019\end{array}$ \\
\hline
\end{tabular}

\section{Keywords}

Adjuvant, Aerobic rice, Irrigation, Nutrient harvest index, Partial factor productivity, Spotplanting, Sterility

\section{A B S T R A C T}

Aerobic rice (Oryza sativa L.) is widely grown in eastern India. Soil moisture stress and unscientific ways of sowing, limit its yield and grain quality. Thus, a field experiment was conducted at Central Rainfed Upland Rice Research Station, Hazaribagh, Jharkhand, India during rainy season of 2016, to study the effects of irrigation regimes, soil adjuvants and planting methods on growth, and uptake and portioning of micro-nutrients in aerobic rice. The experiment was laid-out in a split-plot design replicated thrice. The treatments included 4-irrigation schedules, irrigation at 0.9, 1.2, 1.5 IW/CPE ratio and no-irrigation (rainfed), and 2-soil adjuvants (soil adjuvant applied and no-soil adjuvant) allotted to main-plots and 2-planting methods-conventional dry seeding at $20 \mathrm{~cm}$ row spacing and spot-sowing (dibbling of 4 -seeds/hill at $20 \times 15 \mathrm{~cm}$ interval) to the sub-plots. Irrigation at IW/CPE 1.5 exhibited the highest tiller count which was 4.2, 10.6 and $18.7 \%$ higher than IW/CPE, 1.2, IW/CPE 0.9 and rainfed treatment. The conversion of tillers to effective tillers was higher in IW/CPE 1.5 and 1.2 than water stressed crop (IW/CPE 0.9 and rainfed). Irrigation at IW/CPE ratio 0.9, 1.2 and 1.5 caused 16, 25 and 40\% enhancement in filled-grain weight panicle $^{-1}$, respectively, over rainfed crop; the corresponding reduction in grain sterility was 21,33 and $47 \%$. Total uptake of $\mathrm{Fe}, \mathrm{Zn}, \mathrm{Cu}$ and $\mathrm{Mn}$ went up by 23.3, 24.6, 24.4 and 24.4\%, respectively, in IW/CPE 1.5 over rainfed condition. Micro-nutrient harvest index and partial factor productivity of applied $\mathrm{N}, \mathrm{P}$ and $\mathrm{K}$ also stood highest in IW/CPE 1.5. Spot-planting resulted in significantly larger tiller-count, higher number of panicles $\mathrm{m}^{-2}$ with larger and heavier panicles compared to conventional planting. Micro-nutrient accumulation and harvest index were also higher with spotplanting. Soil adjuvant application did not express significant effect on any of the studied parameters. Hence for better crop growth and accumulation of micro-nutrients and their larger portioning towards grains, aerobic rice should be spot-planted and irrigated at IW/CPE 1.5 under adequate water supply and at IW/CPE 1.2 when water is limited.

\section{Introduction}

Rice (Oryza sativa L.) constitutes staple food for more than half of the India's population and plays an important role in country's food security. India should produce additional 50 $\mathrm{mt}$ of rice at growth rate of $3 \mathrm{~m} \mathrm{t}$ annually to feed 1523 million population by 2030 (CRRI 
2011; Dass et al., 2016). However, the conventional transplanted puddled rice production system is labour, water and energy-intensive, and thus, less remunerative (Kumar and Ladha, 2011). The looming water crisis, climate change, global warming, and poor availability of labour are posing serious limitations to conventional rice cultivation (Sandhu et al., 2017). Rice requires two to three times more water than other cereals and consumes about $70 \%$ of the available irrigation water in India (Biswas, 2010 and Dass and Chandra, 2013a). Humphreys et al., (2010) found that continuous use of ground water for irrigation of rice led to declines in water table by $0.1-1.0 \mathrm{~m}$ per year in Northwest-Indo-Gangetic Plains. The situation is further worsening as the rainfall patterns in many areas are becoming more and more unreliable and erratic, with extremes of drought and flooding occurring regularly due to climate change.

Water scarcity for rice cultivation is felt not only in India, but world over too. In South and Southeast Asia, over 15 million hectare (mha) wetland irrigated rice may experience "physical water scarcity" whereas, 22 mha may experience "economic water scarcity" by 2025 (Tuong and Bouman 2003). Under such circumstances, aerobic rice (AR) can be a potential alternative to transplanted rice. Aerobic rice is a production system where rice is grown in well-drained, non-puddled, and non-saturated soils. The main advantage of AR is increasing water productivity through water saving during land preparation and limiting seepage, percolation, and evaporationand lesser use of labour as compared to transplanted puddle rice (Castaneda et al., 2003; Belder et al., 2004 Peng et al., 2012). However, AR has been successful in cool temperate regions while for sub-tropic and tropic regions, a partial aerobic rice system (PARS) which includes alternate wetting and drying, keep soil at saturation and irrigation at 1-5 days interval, may be more plausible alternative (Prasad, 2011). However, yield penalty also occurs in AR (Farooq et al., 2009), which is mainly due to macro-and micronutrient deficiency or lesser uptake of these nutrients, weeds and root nematodes infestation (Prasad, 2011).

Thus, adequate soil moisture is pre-requisite for macro-and micro-nutrient uptake by plants. Soil water regimes facilitate the maximum micronutrient supply to the crop plants. Indirectly, soil moisture favourably enhances the physicochemical and microbial processes that enable soil to provide micronutrients in available form to the plant. $\mathrm{Zn}$ deficiency occurs under both flooded or anaerobic conditions (Fageria et al., 2003) as well as under aerobic conditions (Prasad, 2011; Farooq et al., 2011). Rainfed areas generally face drought like situations in between the vegetative and flowering stages of rice which is the main factor limiting grain yield. In drought like situations, application of soil adjuvants/surfactants can modify irrigation properties which will enhance water holding capacity (WHC) and allow soil to retain more water and supply to the crop plants in water scarce conditions. Adjuvants include a wide range of chemical compounds, such as surfactants, stickers, sun screen agents, humectants and anti-evaporation agents (Curran et al., 1999). Under limited soil moisture conditions, a soil adjuvant improves the availability of nutrients in soil profile as they are chemically and biologically active compounds. Their mode of action allows water to penetrate and wet agricultural soils more easily, potentially improving water use efficiency (WUE) and crop quality (Karagunduz et al., 2001; Krogh et al., 2003).

Apart from irrigation management, proper spacing and method of planting can maintain the optimum plant population and favourably influence the growth, yield and nutrient 
uptake of plants. Several workers have reported that maintenance of a critical level of rice plant population in field was essential to obtain adequate tiller-count with longer and heavier panicles, and higher yields and nutrient uptake (Shrirame et al., 2000, Sultana et al., 2012 and Dass et al., 2017b). Thus, the objective of this study was to find the effects of irrigation regimes, soil adjuvant and planting methods on growth, and uptake and portioning of micro-nutrients in aerobic rice.

\section{Materials and Methods}

\section{Study area, meteorological parameters}

The field experiment was conducted at Central Rainfed Upland Rice Research Station, Hazaribagh $\left(23^{\circ} 56^{\prime} 34^{\prime \prime} \mathrm{N}\right.$ and $85^{\circ} 21^{\prime} 46^{\prime \prime} \mathrm{E}$ and $614 \mathrm{~m}$ above mean sea level.), Jharkhand. Soil of the experimental field was clay loam in texture, categorised as medium in organic $\mathrm{C}(0.62 \%)$, low in available $\mathrm{N}\left(153 \mathrm{~kg} \mathrm{ha} \mathrm{ha}^{-1}\right)$, medium in available $\mathrm{P}\left(11.3 \mathrm{~kg} \mathrm{ha}^{-1}\right)$ and high in available $\mathrm{K}$ (380 $\left.\mathrm{kg} \mathrm{ha}^{-1}\right)$. The available $\mathrm{Fe}$ and $\mathrm{Zn}$ content was 13.42 and 2.79 ppm, respectively. Soil reaction was in neutral range ( $\mathrm{pH}$ 6.8). Field capacity and permanent wilting point moisture content of soil was $28.7,14.9 \%$, respectively.

The climate of the experimental site is warm and humid with mean maximum and minimum temperature of $31.4^{\circ} \mathrm{C}$ and $13.7^{\circ} \mathrm{C}$, respectively. South-west monsoon normally reaches Hazaribagh on and around $18^{\text {th }}$ of June every year, with year to year deviation of 5-10 days. The normal rainfall of the district is $1083.9 \mathrm{~mm}$, June to September are the usual rainy months accounting for $79 \%$ of the total rainfall. Total rainfall during experimentation period was $1237 \mathrm{~mm}$. The mean maximum temperature was $31.7^{\circ} \mathrm{C}$, while the mean minimum $13.5^{\circ} \mathrm{C}$.

\section{Experimental setup and crop management}

The three-time replicated field experiment was conducted in a split-plot design. The treatments included 8-combinations of 4irrigation schedules [irrigation at IW/ CPE $0.9,1.2,1.5$ and no-irrigation (rainfed)] and 2-soil adjuvants (soil adjuvant applied and nosoil adjuvant) allotted to main-plots, and 2planting methods-conventional dry seeding at $20 \mathrm{~cm}$ row spacing and spot-sowing (dibbling of 4 -seeds/hill at $20 \times 15 \mathrm{~cm}$ interval) to the sub-plots. Thus there were a total of 16 treatment combinations. Fifty milli-meter depth of irrigation water was applied when the cumulative pan evaporation (CPE) reached 56,42 , and $33 \mathrm{~mm}$ in order to get pre-determined IW/CPE ratio of $0.9,1.2$, and 1.5 , respectively. Soil adjuvant (APSA $80^{\mathrm{TM}}$ ) was applied on soil surface twice @ $450 \mathrm{ml}$ $\mathrm{ha}^{-1}$ dissolved in 500 litres of water, once at tillering stage and subsequently at panicle emergence stage.

A high yielding rice variety Sahabhagi Dhan suitable for direct sowing or transplanting in rainfed upland ecosystem was sown using pre-determined methods, namely, conventional planting and spot-sowing. In conventional planting, rice seeds were manually drilled in rows spaced $20 \mathrm{~cm}$ apart using $60 \mathrm{~kg} \mathrm{ha}^{-1}$ seed. In spot-sowing, 4 seeds were dibbled per hill at $20 \times 15 \mathrm{~cm}$ spacing manually, using $30 \mathrm{~kg}$ seed ha ${ }^{-1}$. All plots were equally fertilized with $120 \mathrm{~kg} \mathrm{~N}, 60 \mathrm{~kg}$ $\mathrm{P}_{2} \mathrm{O}_{5}$, and $30 \mathrm{~kg} \mathrm{~K} \mathrm{~K}_{2} \mathrm{O}$. $\mathrm{N}$ was supplied through urea and di-ammonium phosphate (DAP). $\mathrm{P}$ was supplied through DAP and $\mathrm{K}$ from muriate of potash. Half of $\mathrm{N}$ and entire amounts of $\mathrm{P}$ and $\mathrm{K}$ were incorporated basally at the time of sowing. The remaining amount of $\mathrm{N}$ was top-dressed in 2-equal instalments, the first at active tillering and the second at panicle initiation stage. Weeds were controlled with pre-emergence application of pendimethalin@ $1.0 \mathrm{~kg} \mathrm{ha}^{-1}$ followed by 
post-emergence application of bispyribac-Na @ $0.025 \mathrm{~kg} \mathrm{ha}^{-1}$.

\section{Data collection and analysis}

The number of tillers was counted from one square meter demarcated area at 45 days after sowing (DAS), 75 DAS and at harvest stage. Proportion of effective tillers (PEt, \%) was computed by using the following expression.

PEt $(\%)=\frac{\text { Effective tillers per square meter area at harvest }}{\text { Total mumber of tillers per square meter area at } 75 \text { DAS }} \times 100$

Ten representative panicles were selected and number of grains (filled, unfilled) were counted and averaged out to arrive at filled, unfilled grains panicle ${ }^{-1}$. The weights of filled and unfilled grains obtained from each of the 10 sampled panicles were recorded separately using a high precision electronic balance. Sterility percentage was calculated on the basis of number/weight of filled and unfilled grains by using the following expressions:

Sterility $(\%)=\frac{\text { Number of } u n-\text { filled grain or weight of un }- \text { filled grains }}{\text { Total mumber of grains }(\text { filled }+ \text { unfilled }) \text { or their weight }} \times 100$

The $\mathrm{Fe}, \mathrm{Zn}, \mathrm{Mn}$ and $\mathrm{Cu}$ in grain and straw of rice crop were determined by DTPA extractable method (Lindsay and Norvell, 1978). Uptake of $\mathrm{Fe}, \mathrm{Zn}, \mathrm{Cu}$ and $\mathrm{Mn}$ was computed by multiplying the values of their respective concentration in grains and straw with grain and straw yields. For computing grain and straw yields, the crop from the net profit area of $16.38 \mathrm{~m}^{2}$ was harvested plotwise dried, thrashed and weighed. All yields were determined at $14 \%$ moisture content. Partial factor productivity (PFP) and micronutrient harvest index (NHI) were determined using the following expressions:

$$
\text { PFP }(\text { kg grain per } k g \text { mutrient applied })=\frac{\text { Grain yield in } k g / h a}{\text { Amount of mutrient applied } k g / h a} \times 100
$$

$\operatorname{NHI}(\%)=\frac{\text { Micro }- \text { mutrient uptake in grain, } g / \text { ha }}{\text { Total uptake of micro }- \text { mutrient }(\text { grain }+ \text { straw }), g / h a} \times 100$

\section{Statistical analysis}

The experimental data was subjected to statistical analysis by using the standard technique of analysis of variance (ANOVA). The significance of treatment means was tested using F-test (Rana et al., 2014). The critical difference $(\mathrm{P}=0.05)$ were worked out to evaluate differences between treatment means.

\section{Results and Discussion}

\section{Growth and yield attributes}

The irrigation regimes and planting methods revealed significant influences on all the yield attributing characters like tiller-count, filled grain weight panicle ${ }^{-1}$, unfilled grain weight panicle $^{-1}$ and sterility percentage. The effect of soil adjuvant was non-significant. All characters were significantly affected by irrigation levels except tillers count at 45 DAS. At 75 DAS, maximum tillers count $\mathrm{m}^{-2}$ was obtained with irrigations applied at IW/CPE ratio 1.5 which was, however, at par with IW/CPE ratio 0.9 and 1.2. At harvest, IW/CPE 1.5 exhibited the highest tiller count which was $4.2,10.6$ and $18.7 \%$ higher than IW/CPE, 1.2, IW/CPE 0.9 and rainfed treatment; the difference between IW/CPE 1.5 and 1.2 was non-significant. Moreover, the conversion of tillers to effective tillers (panicle bearing tillers) was higher in IW/CPE 1.5 and 1.2 than water stressed crop (IW/CPE 0.9 and rainfed).

A higher tiller mortality as a result of water deficit and resultant inadequate availability in the soil and low absorption of important nutrients $(\mathrm{N}, \mathrm{Fe}, \mathrm{P}$ and $\mathrm{K})$ might be the reasons for lower tillers number and their conversion into effective panicles under 
delayed irrigation (IW/CPE 0.9) and rainfed condition (Dass et al., 2013b, 2016, 2017b).

Increasing frequency of irrigation as depicted by increasing values of IW/CPE ratios, significantly increased filled-grain weight panicle $^{-1}$ in aerobic rice. Irrigation at IW/CPE ratio $0.9,1.2$ and 1.5 led to 16,25 and $40 \%$ enhancement in filled-grain weight panicle ${ }^{-1}$, respectively, over rainfed crop. A reverse trend was, however, observed for unfilledgrain weight panicle ${ }^{-1}$. Grain sterility was also significantly higher in rainfed crop. Grain sterility computed based on filled and unfilled grain number, was $21,33,47 \%$ lower with irrigations scheduled at IW/CPE 0.9, 1.2 and 1.5 , respectively, compared to rainfed crop. The reduction in sterility percentage was significant with increase in irrigation frequency. The lower panicle weight and higher grain sterility under rainfed condition and stressed irrigation regime (IW/ CPE 0.9) could be due to soil moisture stress at most critical stages (grain-filling and flowering). Thomas et al., (2014) also reported the reduction in yield attributing characters of upland rice in rainfed condition. Soil adjuvant application did not increase tiller count, and filled grain weight panicle ${ }^{-1}$ significantly. Due to higher unfilled grain number and weight, sterility percentage was significantly higher in adjuvant excluded plots (Table 1).

Between two planting methods, spot-planting resulted in significantly larger tiller-count, and higher number of panicles $\mathrm{m}^{-2}$ with larger and heavier panicles compared to conventional planting. The increase in filled grain weight panicle ${ }^{-1}$ due to spot-planting was $10 \%$. While sterile grain weight panicle ${ }^{-1}$ was significantly higher in conventional drilling of seeds. The higher number of tillers, panicles $\mathrm{m}^{-2}$ and filled grain weight panicle in spot sowing might be due to larger space, greater availability of light, moisture and nutrients and hence higher photosynthetic rates in spot-planted rice plants (Bezbaruha et al., 2011, Dass 2013a,b, Dass et al., 2015).

\section{Nutrient concentration}

Increasing the irrigation frequency from IW/CPE 0.90 to 1.50 enhanced $\mathrm{Fe}, \mathrm{Zn}, \mathrm{Cu}$ and $\mathrm{Mn}$ concentrations in both rice grain and straw but the differences were nonsignificant. However, levels of irrigation exhibited significant variation in $\mathrm{Fe}, \mathrm{Zn}, \mathrm{Cu}$ and $\mathrm{Mn}$ uptake in both grain and straw. Applying irrigation at IW/CPE 1.50 increased total uptake of $\mathrm{Fe}, \mathrm{Zn}, \mathrm{Cu}$ and $\mathrm{Mn}$ by 23.3, 24.6, 24.4 and $24.4 \%$, respectively, over rainfed condition (Table 2). The respective increase in total uptake of micronutrients $(\mathrm{Fe}$, $\mathrm{Zn}, \mathrm{Cu}$ and $\mathrm{Mn}$ ) by irrigation at IW/CPE 1.2 was $9.1,10.7,13.6$ and $9.7 \%$. Availability of sufficient moisture in the plots irrigated at IW/CPE 1.5 and 1.2 facilitated the plants for higher nutrient uptake through better growth and yield attributes. Hazra and Chandra (2014); Dass and Chandra, 2012; Dass and Dhar, 2014 and Dass et al., 2017b) reported that soil moisture regimes affected the availability and uptake of nutrients in rice significantly. Further, water play an important role in the mobilization of $\mathrm{Fe}, \mathrm{Cu}$ and $\mathrm{Zn}$, their uptake was significantly reduced due to water stress (Oktem, 2008). Soil adjuvant application did not influence concentration and uptake of any of the studied micronutrients significantly. Likewise, planting methods had meagre impact on nutrient concentration and uptake, except grain uptake of $\mathrm{Fe}, \mathrm{Zn}, \mathrm{Cu}$ and $\mathrm{Mn}$ that was significantly higher $(5.8,8.3,10.4$ and $6.3 \%)$ in spotsowing over conventional planting. Higher grain yield led to higher uptake of micronutrients in grain in spot sowing, concentration of all micro-nutrients was alike between two planting methods. Beligar (1986) also noted that the differences in nutrient accumulation by plants are assumed to be depending on dry weight of plant. 


\section{Partial factor productivity}

Partial factor productivity of N, P and K was maximum with irrigation at $1.5 \mathrm{IW} / \mathrm{CPE}$ ratio. Better irrigation regimes created favourable soil environment facilitating plant growth and yield that, in turn, resulted in higher partial factor productivity. Nayak et al., (2015) reported that irrigation at 5- and 3- day intervals produced significantly higher value of partial factor productivity of $\mathrm{N}$ than other irrigation regimes at larger interval. The similar results have also been reported Rahman et al., (2013). Between two planting methods, spot-sowing recorded higher partial factor productivity of all studied nutrients due to higher grain yields. Application of soil adjuvant did not alter the partial factor productivity.

\section{Nutrient harvest index}

Irrigation at IW/ CPE 1.2 and 1.5 improved micro-nutrient harvest index over rainfed crop significantly, barring $\mathrm{Cu}$-harvest index that was similar between IW/CPE 1.2 and rainfed crop (Table 3). A higher moisture availability might have led to greater nutrient availability in soil, their higher uptake via higher grain yield and also increased translocation to grains, under favourable irrigation regimes mediated irrigations at shorter intervals (Dass et al., 2017b). These processes could have culminated into higher nutrient harvest index. Spot-sowing resulted in higher grain yield which caused higher nutrient uptake and nutrient harvest index. The influence of soil adjuvant on nutrient harvest index was insignificant as was on crop growth and yield.

Table.1 Effect of irrigation regimes, soil adjuvant and planting methods on tiller count, grain weight/panicle and sterility in aerobic rice

\begin{tabular}{|c|c|c|c|c|c|c|c|c|}
\hline \multirow[t]{2}{*}{ Treatment } & \multicolumn{3}{|c|}{ Tillers count $\mathbf{m}^{-2}$} & \multirow{2}{*}{$\begin{array}{l}\text { Proportion } \\
\text { of effective } \\
\text { tillers }(\%)\end{array}$} & \multirow{2}{*}{$\begin{array}{l}\text { Filled grain } \\
\text { weight } \\
\text { panicle }^{-1}(\mathrm{~g})\end{array}$} & \multirow{2}{*}{$\begin{array}{c}\text { Unfilled } \\
\text { grain } \\
\text { weight } \\
\text { panicle }^{-1}(g)\end{array}$} & \multicolumn{2}{|c|}{ Sterility \% } \\
\hline & $\begin{array}{c}45 \\
\text { DAS }\end{array}$ & $\begin{array}{c}75 \\
\text { DAS }\end{array}$ & $\begin{array}{l}\text { Harvest } \\
\text { (Effective } \\
\text { tillers) }\end{array}$ & & & & $\begin{array}{c}\text { Grain } \\
\text { number } \\
\text { based }\end{array}$ & $\begin{array}{c}\text { Grain } \\
\text { weight } \\
\text { based }\end{array}$ \\
\hline \multicolumn{9}{|c|}{ Irrigation (IW/CPE ratio) } \\
\hline 0.9 & 164 & 340 & 293 & 86.2 & 2.04 & 0.36 & 27.9 & 14.9 \\
\hline 1.2 & 173 & 343 & 311 & 90.7 & 2.20 & 0.31 & 23.8 & 12.6 \\
\hline 1.5 & 178 & 363 & 324 & 89.3 & 2.46 & 0.25 & 18.6 & 9.2 \\
\hline Rainfed & 162 & 326 & 273 & 83.7 & 1.76 & 0.47 & 35.4 & 21.3 \\
\hline SEm \pm & 4.97 & 7.94 & 7.75 & - & 0.056 & 0.01 & 0.68 & 0.47 \\
\hline $\mathrm{CD}(\mathrm{P}=\mathbf{0 . 0 5})$ & NS & 24.1 & 23.5 & - & 0.168 & 0.03 & 2.05 & 1.44 \\
\hline \multicolumn{9}{|l|}{ Soil adjuvant } \\
\hline$A_{1}$ & 172 & 346 & 304 & 87.9 & 2.16 & 0.34 & 25.5 & 13.9 \\
\hline $\mathbf{A}_{2}$ & 167 & 340 & 297 & 87.4 & 2.07 & 0.36 & 27.4 & 15.1 \\
\hline SEm \pm & 3.52 & 5.61 & 5.48 & - & 0.04 & 0.007 & 0.48 & 0.33 \\
\hline $\mathrm{CD}(\mathrm{P}=0.05)$ & NS & NS & NS & - & NS & NS & 1.45 & 1.01 \\
\hline \multicolumn{9}{|c|}{ Planting method } \\
\hline $\mathbf{P}_{1}$ & 165 & 337 & 292 & 86.6 & 2.02 & 0.36 & 28.0 & 15.5 \\
\hline $\mathbf{P}_{2}$ & 174 & 349 & 308 & 88.3 & 2.22 & 0.33 & 24.9 & 13.5 \\
\hline SEm \pm & 2.9 & 3.9 & 5.1 & - & 0.04 & 0.01 & 0.47 & 0.31 \\
\hline $\mathrm{CD}(\mathbf{P}=\mathbf{0 . 0 5})$ & 8.6 & 11.6 & 15.4 & - & 0.12 & 0.014 & 1.41 & 0.91 \\
\hline
\end{tabular}


Table.2 Effect of irrigation regimes, soil adjuvant and planting methods on nutrient concentration and uptake

\begin{tabular}{|c|c|c|c|c|c|c|c|c|c|c|c|c|c|c|c|c|c|c|c|c|}
\hline \multirow[t]{2}{*}{ Treatment } & \multicolumn{2}{|c|}{$\begin{array}{c}\text { Fe- } \\
\text { concentration } \\
\left(\mathrm{mg} \mathrm{kg}^{-1}\right)\end{array}$} & \multicolumn{3}{|c|}{$\begin{array}{c}\text { Fe-uptake } \\
\left(\mathrm{g} \mathrm{ha}^{-1}\right)\end{array}$} & \multicolumn{2}{|c|}{$\begin{array}{c}\mathrm{Zn}- \\
\text { concentration } \\
\left(\mathrm{mg} \mathrm{kg}^{-1}\right)\end{array}$} & \multicolumn{3}{|c|}{$\begin{array}{l}\text { Zn- uptake } \\
\quad\left(\mathrm{g} \mathrm{ha}^{-1}\right)\end{array}$} & \multicolumn{2}{|c|}{$\begin{array}{c}\mathrm{Cu}- \\
\text { concentration } \\
\left(\mathrm{mg} \mathrm{kg}^{-1}\right)\end{array}$} & \multicolumn{3}{|c|}{$\begin{array}{l}\text { Cu- uptake } \\
\quad\left(\mathrm{g} \mathrm{ha}^{-1}\right)\end{array}$} & \multicolumn{2}{|c|}{$\begin{array}{c}\text { Mn- } \\
\text { concentration } \\
\left(\mathrm{mg} \mathrm{kg}^{-1}\right)\end{array}$} & \multicolumn{3}{|c|}{$\begin{array}{l}\text { Mn- uptake } \\
\quad\left(\mathrm{g} \mathrm{ha}^{-1}\right)\end{array}$} \\
\hline & Grain & Straw & Grain & Straw & Total & Grain & Straw & Grain & Straw & Total & Grain & Straw & Grain & Straw & Total & Grain & Straw & Grain & Straw & Total \\
\hline \multicolumn{21}{|c|}{ Irrigation (IW/CPE ratio) } \\
\hline 0.9 & 75.3 & 132.3 & 241 & 804 & 1045 & 28.9 & 68.9 & 92 & 419 & 511 & 5.6 & 20.7 & 17.9 & 113 & 131 & 34.3 & 85.4 & 110 & 519 & 629 \\
\hline 1.2 & 77.2 & 134.9 & 274 & 852 & 1126 & 30.2 & 70.7 & 107 & 445 & 552 & 6.1 & 21.6 & 21.7 & 125 & 147 & 36.0 & 87.2 & 128 & 551 & 678 \\
\hline 1.5 & 79.2 & 137.8 & 332 & 1003 & 1335 & 31.2 & 71.9 & 131 & 523 & 654 & 6.4 & 21.9 & 26.3 & 142 & 168 & 37.3 & 89.7 & 157 & 653 & 810 \\
\hline Rainfed & 74.9 & 131.4 & 232 & 792 & 1024 & 27.7 & 67.8 & 86 & 407 & 493 & 5.9 & 19.7 & 18.2 & 108 & 127 & 33.7 & 84.5 & 104 & 508 & 612 \\
\hline SEm \pm & 1.85 & 2.75 & 7.1 & 23.7 & 30.5 & 0.81 & 0.81 & 2.8 & 12.5 & 15.2 & 0.2 & 0.2 & 1.0 & 6.2 & 6.9 & 0.9 & 2.2 & 3.5 & 15.5 & 18.8 \\
\hline $\begin{array}{l}\text { CD } \\
P=0.05)\end{array}$ & NS & NS & 21.65 & 71.9 & 92.6 & NS & NS & 8.5 & 38.0 & 45.9 & NS & NS & 2.94 & 18.9 & 20.9 & NS & NS & 10.7 & 47.0 & 56.9 \\
\hline \multicolumn{21}{|l|}{ Soil adjuvant } \\
\hline $\mathbf{A}_{1}$ & 77.1 & 134.8 & 272 & 870 & 1142 & 29.8 & 70.1 & 107 & 452 & 557 & 6.0 & 21.2 & 21.1 & 124 & 145 & 36 & 87 & 127 & 564 & 690 \\
\hline $\mathbf{A}_{2}$ & 76.2 & 133.4 & 268 & 856 & 1124 & 29.2 & 69.5 & 102 & 445 & 548 & 6.0 & 20.7 & 20.9 & 120 & 141 & 35 & 86 & 122 & 552 & 674 \\
\hline SEm \pm & 1.31 & 1.94 & 5.1 & 16.8 & 21.6 & 0.58 & 1.142 & 2.0 & 8.9 & 10.7 & 0.14 & 0.41 & 0.69 & 4.4 & 4.9 & 0.7 & 1.5 & 2.5 & 11.0 & 13.3 \\
\hline $\begin{array}{c}\text { CD } \\
(\mathbf{P}=\mathbf{0 . 0 5})\end{array}$ & NS & NS & NS & NS & NS & NS & NS & NS & NS & NS & NS & NS & NS & NS & NS & NS & NS & NS & NS & NS \\
\hline \multicolumn{21}{|c|}{ Planting method } \\
\hline $\mathbf{P}_{1}$ & 76.5 & 133.9 & 262 & 851 & 1114 & 29.0 & 69.3 & 100 & 440 & 540 & 5.8 & 20.6 & 19.9 & 117 & 137 & 35.2 & 86.5 & 121 & 550 & 671 \\
\hline $\mathbf{P}_{2}$ & 76.8 & 134.3 & 278 & 874 & 1152 & 30.0 & 70.3 & 109 & 457 & 565 & 6.2 & 21.3 & 22.2 & 127 & 149 & 35.4 & 86.9 & 129 & 565 & 694 \\
\hline SEm \pm & 0.97 & 1.57 & 4.5 & 13.8 & 18.2 & 0.52 & 0.95 & 1.5 & 6.5 & 7.8 & 0.13 & 0.28 & 0.48 & 1.9 & 2.05 & 0.44 & 1.13 & 1.6 & 7.7 & 9.3 \\
\hline $\mathrm{CD}(\mathrm{P}=0.05)$ & NS & NS & 13.55 & NS & NS & NS & NS & 4.6 & NS & 23.3 & NS & NS & 1.44 & 5.7 & 6.2 & NS & NS & 4.8 & NS & NS \\
\hline
\end{tabular}


Table.3 Effect of irrigation regimes, soil adjuvant and planting methods on partial factor productivity of applied nutrients and micro-nutrient harvest index

\begin{tabular}{|c|c|c|c|c|c|c|c|}
\hline \multirow[t]{2}{*}{ Treatment } & \multicolumn{3}{|c|}{$\begin{array}{l}\text { Partial factor productivity (kg } \\
\text { ha }^{-1} \mathrm{~kg}^{-1} \text { of applied nutrients) }\end{array}$} & \multicolumn{4}{|c|}{ Nutrient harvest index (\%) } \\
\hline & $\mathbf{P F P}_{\mathbf{N}}$ & $\mathbf{P F P}_{\mathbf{P}}$ & $\mathbf{P F P}_{K}$ & $\mathbf{F e}$ & $\mathbf{Z n}$ & $\mathrm{Cu}$ & Mn \\
\hline \multicolumn{8}{|c|}{ Irrigation (IW/CPE ratio) } \\
\hline 0.9 & 27.9 & 55.9 & 111.8 & 23.1 & 18.1 & 13.7 & 17.4 \\
\hline 1.2 & 30.2 & 60.5 & 120.9 & 24.4 & 19.4 & 14.8 & 18.8 \\
\hline 1.5 & 34.3 & 68.7 & 137.3 & 24.8 & 20.0 & 15.8 & 19.4 \\
\hline Rainfed & 25.0 & 50.0 & 100.1 & 22.7 & 17.5 & 14.4 & 17.1 \\
\hline SEm \pm & 0.815 & 1.63 & 3.26 & 0.16 & 0.17 & 0.54 & 0.17 \\
\hline $\mathrm{CD}(\mathrm{P}=0.05)$ & 2.47 & 4.95 & 9.89 & 0.49 & 0.52 & 1.63 & 0.51 \\
\hline \multicolumn{8}{|l|}{$\begin{array}{l}\text { Soil } \\
\text { adjuvant }\end{array}$} \\
\hline $\mathbf{A}_{1}$ & 29.6 & 59.1 & 118.3 & 23.7 & 18.9 & 14.6 & 18.3 \\
\hline $\mathbf{A}_{2}$ & 29.2 & 58.4 & 116.8 & 23.8 & 18.6 & 14.7 & 18.0 \\
\hline SEm \pm & 0.58 & 1.15 & 2.31 & 0.11 & 0.12 & 0.38 & 0.12 \\
\hline $\mathrm{CD}(\mathrm{P}=\mathbf{0 . 0 5})$ & NS & NS & NS & NS & NS & NS & $\mathrm{NS}$ \\
\hline \multicolumn{8}{|c|}{ Planting method } \\
\hline $\mathbf{P}_{1}$ & 28.4 & 56.8 & 113.6 & 23.5 & 18.4 & 14.5 & 17.9 \\
\hline $\mathbf{P}_{2}$ & 30.4 & 60.7 & 121.4 & 24.0 & 19.1 & 14.8 & 18.4 \\
\hline SEm \pm & 0.40 & 0.82 & 1.64 & 0.10 & 0.12 & 0.34 & 0.06 \\
\hline $\mathrm{CD}(\mathrm{P}=\mathbf{0 . 0 5})$ & 1.23 & 2.45 & 4.90 & 0.29 & 0.34 & 1.04 & 0.19 \\
\hline
\end{tabular}

Fig.1 Correlation between effective tillers and grain yield of aerobic rice

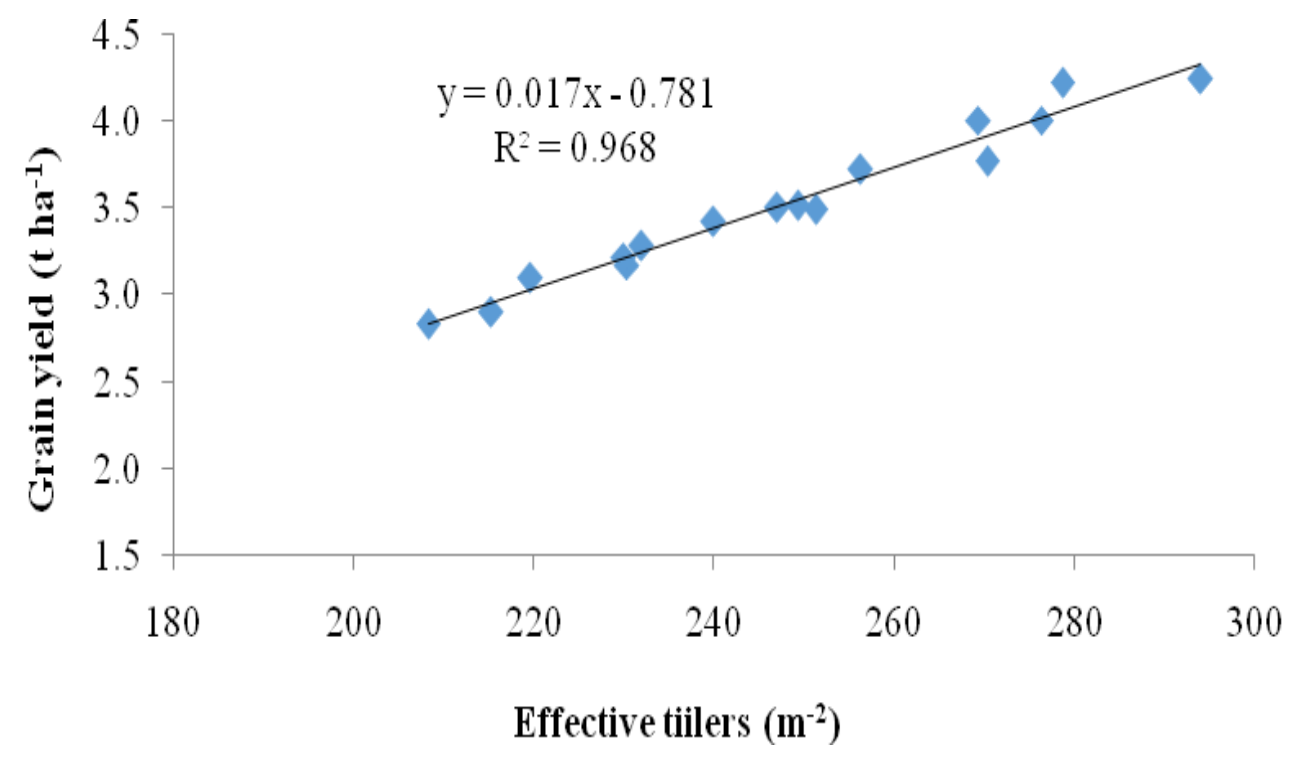


Fig.2 Correlation between dry matter accumulation and grain yield of aerobic rice

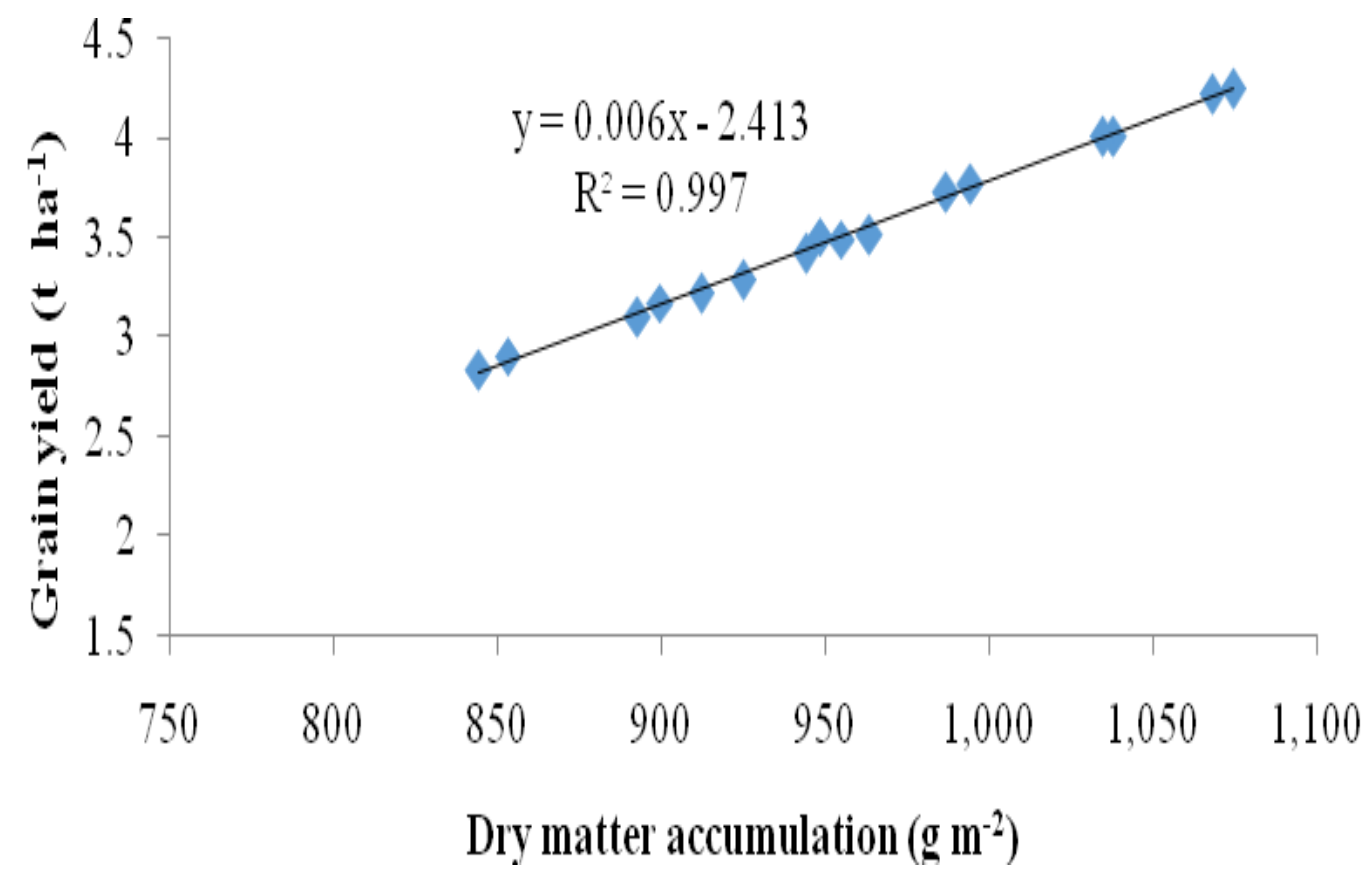

Fig.3 Correlation between filled-grains weight and grain yield of aerobic rice

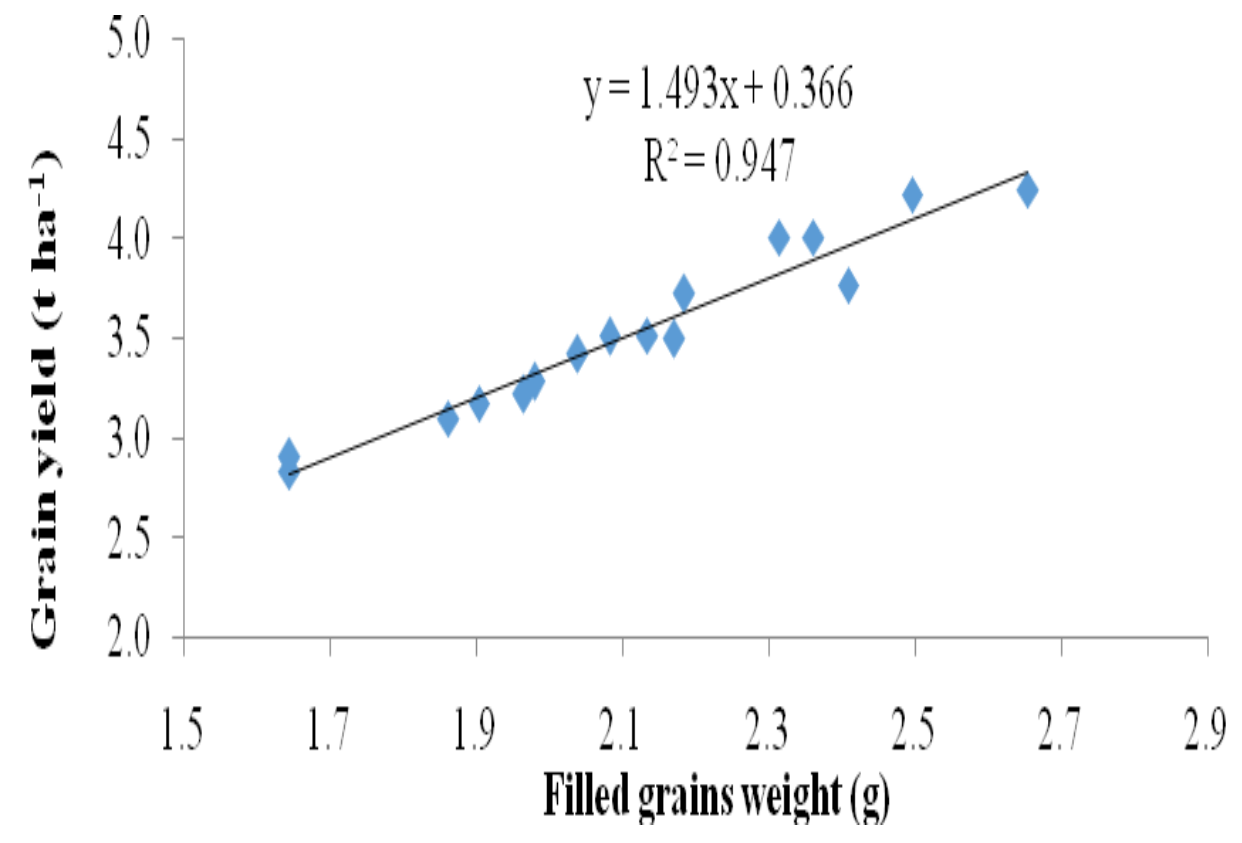




\section{Correlation of growth with yield}

Effective tillers, dry matter accumulation and filled grain weight, were positively correlated with rice grain yield (Figs. 1, 2, 3). Yield formation in rice largely depends upon tiller production, more that $80 \%$ rice yield is contributed by tillers/ $\mathrm{m}^{2}$ (Baloch et al., 2002; Dass et al., 2013a,b). Thus, a positive and significant correlation between tiller count and grain yield of aerobic rice could also be expected. Similarly, a higher overall dry matter production, which is accumulation of carbohydrates, makes possible the higher transport to and accumulation of dry matter in grain finally resulting in larger yield attributes and grain yield. Thus, both drymatter accumulation and panicle weight were positively and significantly correlated with grain yield in the current study also (Dass et al., 2013b).

In conclusion, the current study clearly demonstrates that for better crop growth and higher accumulation of micro-nutrients and their larger portioning towards grains, aerobic rice should be spot-planted. Irrigations should be applied at IW/CPE 1.5 under adequate water supply and at IW/CPE 1.2 when water is limited. These findings are applicable in sub-humid eastern India and other similar agro-ecologies of South-Asian rice production systems.

\section{References}

Baloch, A. W., Soomro, A. M., Javed, M. A., Ahmed, M., Bughio, H. R., Bughio, M. S. and Mastoi, N. N. 2002. Optimum plant density for high yield in rice (Oryza sativa L.). Asian Journal of Plant Science 1:25-27.

Belder, P., Bouman, B.A.M., Cabangon, R., Lu, G., Quilang, E.J. P., Li, Y.H., Spiertz, J.H.J. and Tuong, T.P. 2004. Effect of water-saving irrigation on rice yield and water use in typical lowland conditions in Asia. Agricultural Water Management 65: 193-210.

Beligar, V.C. 1986. Interrelationships between growth and nutrient uptake in alfalfa and corn Journal of Plant Nutrition 9:1391-1404

Bezbaruha, R, Sharma R. C., Banik P. 2011. Effect of Nutrient Management and Planting Geometry on Productivity of Hybrid Rice (Oryza sativa L.) Cultivars. American Journal of Plant Sciences 2: 297-302

Biswas, B.C. (2010). System of rice intensification: success stories of farmers. Fertilizer Marketing News 3-6 July. Available at: http://www.faidelhi.org/Article\%20-

Dr\% 20Biswas/Dr 20\%

B\%20C\%20Biswas\%20-

\%20July\%20issue\%20of\%20Mktg\%20 news.pdf; last accessed 26 December 2012.

Castaneda, A.R., Bouman, B.A.M., Peng, S. and Visperas, R.M. 2003. The potential of aerobic rice to reduce water use in water-scare irrigated low-lands in the tropics. In: Water Wise Rice Production (B A M Bouman, H Hengsdijk, B Hardy, P S Bindraban, T P Toung and J K Ladha, Eds.). IRRI, Los Banos, Philippines.

CRRI. 2011. Vision 2030 Central Rice Research Institute, Indian Council of AgriculturalResearch, Cuttack (Odisha) 753 006, India

Curran, W.S., McGlamery, M.D. Liebl, R.A. and Lingenfelter, D.D. 1999. Adjuvant for enhancing herbicide performance. Agronomy Facts 37: 1-7.

Dass, A., Kaur Ramanjit, Choudhary Anil K., Pooniya V., Rana, D.S., Raj, Rishi and Rana K.S. 2015. System of Rice (Oryza sativa L.) Intensification for higher productivity and resource-use efficiency-A review. Indian Journal of 
Agronomy 60 (1): 1-19

Dass, A. and Chandra, Subhash. 2013a. Irrigation, spacing and cultivar effects on net photosynthetic rate, dry matter partitioning and productivity of rice under SRI in Mollisols of northern India. Experimental Agriculture 49(4):504-523

Dass A. and Chandra, S. 2013b. Panicle characteristics, yield and their correlation in system of rice (Oryza sativa) intensification under variable irrigation, spacing and varieties against conventional transplanting. Indian Journal of Agronomy. 58(1): 126-134

Dass, A. and Chandra, S. 2012. Effect of different components of SRI on yield, quality, nutrient accumulation and economics of rice (Oryza sativa) in tarai belt of northern India. Indian Journal of Agronomy 57(3): 250-254.

Dass, A. and Dhar, S. 2014. Irrigation management for improving productivity, nutrient uptake, and water-use efficiency in SRI: a review. Annals of Agricultural Research, New Series 35(2): 107-122

Dass, A., Chandra, S, Uphoff, N., Choudhary, A. K., Bhattacharyya, R. and Rana, KS. 2017b. Agronomic fortification of rice grains with secondary and micronutrients under differing crop management and soil moisture regimes in the north Indian Plains. Paddy and Water Environment 15(4): 745-760.

Dass, A., Chandra, S., Choudhary, A.K., Singh, G. and Sudhishri, S. 2016. Influence of field re-ponding pattern and plant spacing on rice root-shoot characteristics, yield, and water productivity of two modern cultivars under SRI management in Indian Mollisols. Paddy and Water Environment 14:45-59

Dass, A., Shekhawat, K., Choudhary, Anil K., Sepat, S., Rathore, S.S, Mahajan, G. and
Chauhan, B.S. 2017a. Weed management in rice using cropcompetition. Crop Protection 95: 4552.

Fageria, N.K., Slaton, N.A. and Baligar, V.C. 2003. Nutrient management for improving lowland rice productivity and sustainability. Advances in Agronomy 80: 63-152.

Farooq, M., Kobayashi, N., Wahid, A., Ito, O. and Basar, S.M.A. 2009. Strategies for producing more rice with less water. Advances in Agronomy 101: 351-388.

Farooq, M., Siddique, K.H.M., Rehman, H., Aziz, T., Lee, D.J. and Wahid, A. 2011. Rice direct seeding: experiences, challenges and opportunities. Soil and Tillage Research 111: 87-98.

Hazra, K.K. and Chandra, S. 2014. Mild-to prolonged-stress increased rice tillering and source-to-sink nutrient translocation under SRI management. Paddy and Water Environment 12:245-250.

Humphreys E. et al., 2010. Halting the groundwater decline in north-west India-Which crop technologies will be winners? Advances in Agronomy 109: 155-217.

Karagunduz, A., Pennell, K.D. and Young, M.H. 2001. Influence of a non-ionic surfactant on the water retention properties of unsaturated soils. Soil Science Society of America Journal 65: 1392-1399.

Krogh, K.A., Halling, S.B., Mogensen, B.B. and Vejrup, K.V. 2003. Environmental properties and effects of non-ionic surfactant adjuvants in pesticides: a review. Chemosphere 50: 871901.

Kumar, V., Ladha, J.K. 2011. Direct seeding of rice: recent developments and future research needs. Advances in Agronomy 111:296-413.

Lindsay, WL, Norvell, W.A., 1978. Development of DTPA soil test for zinc, iron, manganese and copper. Soil 
Science Society of America Journal 42:421-428.

Nayak, B.R., Pramanik K., Panigrahy N., Dash A. K. and Swain S. K. 2015.Yield, nitrogen uptake and nitrogen use efficiency indices of aerobic rice (Oryza sativa L.) under various irrigation regimes and nitrogen levels. International Journal of Bio-resource, Environment and Agricultural Sciences (IJBEAS) 1(2): 8-13.

Oktem, A. 2008. Effect of water shortage on yield, protein and mineral compositions of drip irrigated sweet corn in sustainable agricultural systems. Agricultural Water Management 95:1003-1010.

Peng, N.L., Bing, S., Chen, M.X., Shah, F., Huang, J.L., Cui, K.H. and Jing, X. 2012. Aerobic rice for water-saving agriculture-a review. Agronomy for Sustainable Development 32(2): 411418.

Prasad, R. 2011. Aerobic rice system. Advances in Agronomy 111: 207-247.

Rahman, S. and Sinha, A.C. 2013. Effect of water regimes and organic sources of nutrients for higher productivity and nitrogen use efficiency of summer rice. African Journal of Agricultural Research 48: 6189-6195.

Rana, K.S., A.K. Choudhary, S. Sepat, R.S. Bana, and Dass, A. 2014. Methodological and Analytical Agronomy. PG School, IARI, New
Delhi, India. Pp. 276.

Sandhu N., Singh V., Sihag M.K., Jain S., Jain R.K. 2017. Developing climate smart aerobic rice varieties for addressing the problems of water scarcity and global warming. In: Gahlawat S., Salar R., Siwach P., Duhan J., Kumar S., Kaur P. (eds) Plant Biotechnology: Recent Advancements and Developments. Springer, Singapore.

Shrirame, M.D., Rajgire, H.J. and Rajgire, A.H. 2000. Effect of spacing and seedling number per hill on growth attributes and yield of rice hybrids under lowland condition. Journal of Soils and Crops 10(1): 109-113.

Sultana, M.R., Rahman, M.M. and Rahman, M.H. 2012. Effect of row and hill spacing on the yield performance of boro rice (cv. BRRI Dhan 45) under aerobic system of cultivation. Journal of Bangladesh Agricultural University 10(1): 39-42.

Thomas, U.C., Varughese, K. and Thomas, A. 2014. Response of upland rice to differential levels of irrigation, nutrients and seed priming. Journal of Aquatic Biology and Fisheries 2: 775-779

Toung, T.P. and Bouman, B.A.M. 2003. Rice production in water-scare environments. In: Water Productivity in Agriculture: Limits and Opportunities for Improvements" (J W Kijne, R Baker and Molden, Eds.), CABI, UK, pp. 5367.

\section{How to cite this article:}

Arjun Singh, Anchal Dass, Shiva Dhar, C.V. Singh, S. Sudhishri, Teekam Singh, G.A. Rajanna and Pooja Pande. 2019. Water Management and Planting Methods Influence Growth, Spikelet Sterility and Nutrient Acquisition in Aerobic Rice. Int.J.Curr.Microbiol.App.Sci. 8(02): 554565. doi: https://doi.org/10.20546/ijcmas.2019.802.063 